\title{
Utilization of Chitosan Gel Beads as Supports of Fungus Trichoderma viride Cells for Cellulase Production
}

\author{
Hideo Kusaoke and Akihiko Kato \\ Faculty of Engineering, Fukui Institute of Technology, Fukui, 910 Japan
}

\begin{abstract}
Cells of Trichoderma viride, a cellulolytic fungus, were immobilized in chitosan gel beads and employed for producing cellulase by a repeating batch procedure. The activity of the immobilized cells increased with extending culture period, and reached a maximum, $37 \mu \mathrm{g}$ of reducing sugars per $\mathrm{mL}$ of culture filtrate, in 6 days. This value was about $1 / 4$ of that for free cells. The enzyme activity of chitosan gel-immobilized cells in the repeated, batch culture retained about $50 \%$ of the initial activity after ten times of batch culture.
\end{abstract}

\section{Introduction}

Enzyme production by immobilized microbial cells is an active research area despite the fact that industrial applications are still limited [1]. Immobilized cells have unique properties as a biocatalyst and can provide the basis for a continuous process. Methods for immobilizing intact cells have been confined to the entrapment in a hydrophilic polymer matrix such as polyacrylamide, sodium alginate, and carrageenan [2.6]. As a result of immobilization, the rate of the desired enzyme reaction is often suppressed by the diffusion barrier presented to the substrate or oxygen by the polymer matrix.

Aerobic bacterium, Bacillus sp., was first immobilized several years ago using polyacrylamide [7] and car. rageenan [8] gels. In our previous paper [9], we reported that chitosanase production could be performed by immobilized bacterial cells, Alcaligenes faecalis, using calcium alginate gels. We have also reported the investigation on utilization of chitosan derivatives as supports for immobilization of microorganism cells $[10]$ and enzymes.

In this work, the immobilization of an aerobic filamentous fungus Trichodema viride, has been studied using chitosan gel beads. Kumakura et al. (11) reported that aerobic cells such as Trichodema reesei were immobilized with fibrous substances, the fibrils of which were attached by radiation polymerization of hydroxy. ethyl methacrylate and that the immobilized cells grew on the surface of the fibrils. Seo [12] reported that the gel strength of the chitosan gel beads was higher than that of polysaccharides such as agarose and dextran. A chitosan bead, which is spherical in shape and has more than $100 \mathrm{~m}^{2} / \mathrm{g}$ of specific surface area, forms a micro. pore structure with $0.1-0.2 \mu \mathrm{m}$ of pore diameter. Therefore, the use of chitosan beads as a support is expecting for the effective enzyme production by the immobilized cells.

Recently, the enzymatic hydrolysis of cellulosic wastes with cellulase has been studied with the objective of biomass conversion and many works have focused on the use of cellulase from Trichoderma viride grown aerobical. ly on cellulose. Cellulase production by $T$. viride in a continuous culture is very important for reducing the cost of the cellulase production.

\section{Experimental}

\subsection{Chemicals}

The purified chitosan (degree of deacetylation, 97\%) from crab powders was kindly supplied by KATAKURA CHIKKARIN Co. Ltd. All other materials were of the highest grade commercially available.

\subsection{Culture of Microorganism}

Trichoderma viride (IFO 31137) was cultured in a medium containing $2.0 \mathrm{~g}$ of malt extract, $2.0 \mathrm{~g}$ of glucose, and $1.0 \mathrm{~g}$ of peptone in $1 \mathrm{~L}$ of deionized water in a $2 \mathrm{~L}$ Erlenmeyer flask. The $\mathrm{pH}$ was adjusted to 6.0 with $1 \mathrm{~N}$ $\mathrm{HCl}$. The cultivation was carried out aerobically at $28^{\circ} \mathrm{C}$ for $48 \mathrm{~h}$ on a rotary shaker $(120 \mathrm{rpm})$. After the cultivation, cells were harvested by centrifugation at $7800 \times g$ for $15 \mathrm{~min}$, washed with a $0.9 \% \mathrm{NaCl}$ solution, and used for immobilization. 
Table 1 Composition of Cellulase Production Medium ${ }^{\text {a) }}$

\begin{tabular}{lc}
\hline \multicolumn{1}{c}{ Component } & $\begin{array}{c}\text { Concentration } \\
(\mathrm{g} / \mathrm{L})\end{array}$ \\
\hline Microcrystalline cellulose & 7.5 \\
Peptone & 0.75 \\
Tween 80 & 2.0 \\
Urea & 0.3 \\
$\mathrm{KH}_{2} \mathrm{PO}_{4}$ & 2.0 \\
$\left(\mathrm{NH}_{4}\right)_{2} \mathrm{SO}_{4}$ & 1.4 \\
$\mathrm{MgSO}_{4} \cdot 7 \mathrm{H}_{2} \mathrm{O}$ & 0.6 \\
$\mathrm{CaCL}_{2} \cdot 2 \mathrm{H}_{2} \mathrm{O}$ & 0.4 \\
$\mathrm{FeSO}_{4} \cdot 7 \mathrm{H}_{2} \mathrm{O}$ & $5.0 \times 10^{-3}$ \\
$\mathrm{MnSO}_{4} \cdot 4 \mathrm{H}_{2} \mathrm{O}$ & $2.2 \times 10^{-3}$ \\
$\mathrm{ZnSO}_{4} \cdot 4 \mathrm{H}_{2} \mathrm{O}$ & $1.4 \times 10^{-3}$ \\
$\mathrm{CoCl}_{2} \cdot 6 \mathrm{H}_{2} \mathrm{O}$ & $3.6 \times 10^{-3}$ \\
\hline
\end{tabular}

a) The medium containing culture components except urea was adjusted to $\mathrm{pH} 7.0$ and was sterilized by autoclaving at $121{ }^{\circ} \mathrm{C}$ for $15 \mathrm{~min}$. Urea was filter sterilized and added to the culture medium.

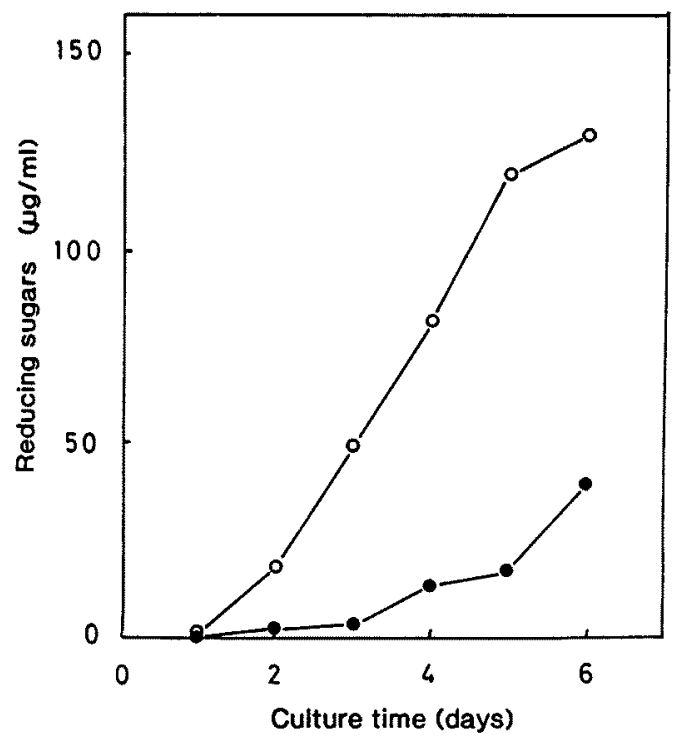

Fig. 1 Enzyme production by free Trichoderma viride (O) and $T$, viride immobilized in chitosan gel beads (O)

\subsection{Immobilization}

The $\mathrm{pH}$ of $2 \%(\mathrm{w} / \mathrm{v})$ chitosan hydrochloride solution was adjusted to 6.0 with $4 \mathrm{~N} \mathrm{HCl}$. Wet $T$. viride cells (1g) were suspended in $40 \mathrm{~mL}$ of the chitosan solution. This suspension was dropped into a $1.5 \%(\mathrm{w} / \mathrm{v}) \mathrm{Na}$-tri- polyphosphate solution $(\mathrm{pH} 8.3)$ with a No. 18 syringe needle under slow stirring. After shrinking and hardening for $2 \mathrm{~h}$, the biocatalyst gel beads were washed with $0.1 \mathrm{M}$ phosphate buffer ( $\mathrm{pH} 7.2$ ). Gel beads were immersed in a $0.05 \%$ glutaraldehyde solution for $15 \mathrm{~min}$ at room temperature and washed with destilled water. The beads were uniform in diameter $(2-3 \mathrm{~mm})$.

\subsection{Enzyme Production}

For experiments with free cells, $2 \mathrm{~mL}$ of broth precultured for $18 \mathrm{~h}$ at $28{ }^{\circ} \mathrm{C}$ was inoculated into $50 \mathrm{~mL}$ of an enzyme production medium (Table 1 ) and incubated at $28^{\circ} \mathrm{C}$ in a $200 \mathrm{~mL}$ Elenmeyer flask on a reciprocating shaker ( 85 strokes/min), usually for 6 days. For experiments with immobilized cells, $1 \mathrm{~g}$ of wet gel beads was incubated in $50 \mathrm{~mL}$ of the same medium in a $200 \mathrm{~mL}$ Elenmeyer flask as above at $28{ }^{\circ} \mathrm{C}$ pH 7.0 , usually for 6 days per one batch. After 6 days the beads were re moved, washed three times with $0.1 \mathrm{M}$ phosphate buffer (pH 7.2) and reincubated in a fresh production medium.

\subsection{Assay of Cellulase}

Cellulase activity were determined by the amount of reducing sugars produced from cellulose. Cellulose $(50$ mg) was added to the solution composed of $5.0 \mathrm{~mL}$ of 0.1 $\mathrm{M}$ acetate buffer $(\mathrm{pH} 4.6)$ and $0.5 \mathrm{~mL}$ culture filtrate. The mixture was incubated at $50{ }^{\circ} \mathrm{C}$ for $1 \mathrm{~h}$. The reducing sugars produced in the mixture were assayed by the Nelson-Somogyi method[13].

\section{Results and Discussion}

\subsection{Cellulase Production of Free and Immobilized Cells}

Fig. 1 shows the time course of the enzyme activity for cellulase producted by free and immobilized $T$. viride cells. The unit of cellulase activity was defined as $\mathrm{mg}$ of reducing sugars produced per $\mathrm{mL}$ of reaction solution. Cellulase activity of free cells of $T$. vinide increased grad ually with the increase in culture time, and was $127 \mu$ $\mathrm{g} / \mathrm{mL}$ after 6 days. On the other hand, the cellulase activity of immobilized cells increased rapidly after 4 days and was $39 \mu \mathrm{g} / \mathrm{mL}$ after 6 days. If a relatively high cellulase activity were desired, the cultivation should be continued for about one week under the experimental conditions employed. However, the activity of cellulase by the immobilized cells was significantly low, about $1 / 4$ of that for free cells. At the culture of 6 days, dry weight of free cells was $30 \mathrm{mg}$ per $50 \mathrm{~mL}$, culture medium, and that of cells immobilized in gels was $0.7 \mathrm{mg}$. This 
observation shows that the growth of $T$. viride cells was restricted because they were entrapped in chitosan gel beads.

Leakage of the cells from the gel beads was observed with the increase in the amount of immobilized cells. This indicates that the apparent bulk of the immobilized cells increased during culture as the results of the active growth of the cells. To protect the diffusion of cells into medium, cells immobilized in chitosan gel beads were treated with $0.05 \%$ glutaraldehyde. Fig. 2 shows the time

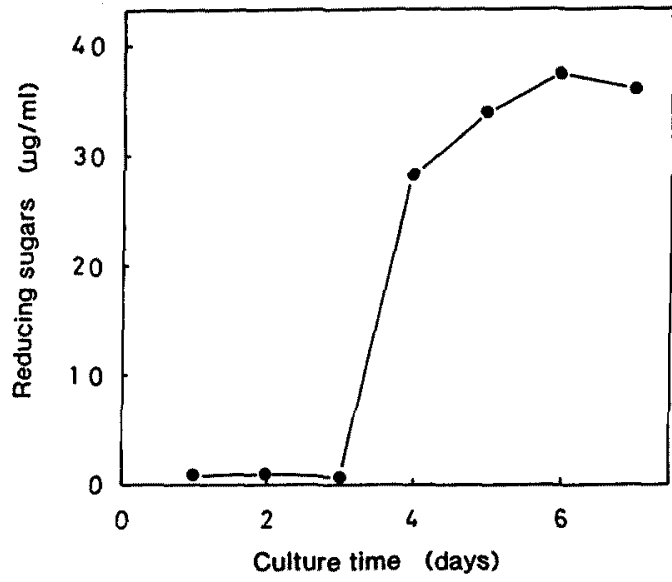

Fig. 2 Enzyme production by $T$. vinide immobilized in chitosan gel beads linked with glutaraldehyde. course of the enzyme activity of the cellulase by cells im. mobilized in gel beads linked with glutaraldehyde. Cellu. lase was produced on culture over 4 days, and reached a maximum, $37 \mu \mathrm{g} / \mathrm{mL}$, after 6 days without leakage of the cells into the medium. With the increase in the cul. ture time to over 6 days, contents of reducing sugars slightly decreased. Cellulase production by the immobil. ized cells may be reduced after 6 days, for the swelling of the gel was observed for the culture after 6 days and aliquotes of the immobilized cells leaked out of gel into medium. The induction period in enzyme production by the immobilized cells was longer than that for free cells (Figs. 1 and 2). It seems that, in the immobilized cells, the rate of the incorporation of nutrients into the im mobilized cells was slower than that into the free cells because of the trapping of the cells in the gels.

\subsection{Cellulase Production by the Immobilized Cells in the Repeated Batch Cycles.}

The repeating use of the immobilized cells in the batch culture was examined. In the repeated batch culture, cel lulase activity of the culture medium was measured after every culture and the culture medium was replaced by a new medium. Fig. 3 shows the relationship between cel. lulase activity and repetition number of batch culture. Cell survival was almost constant for repeated culture, about $50 \mathrm{mg}$ as wet weight of cells per Ig wet gel beads

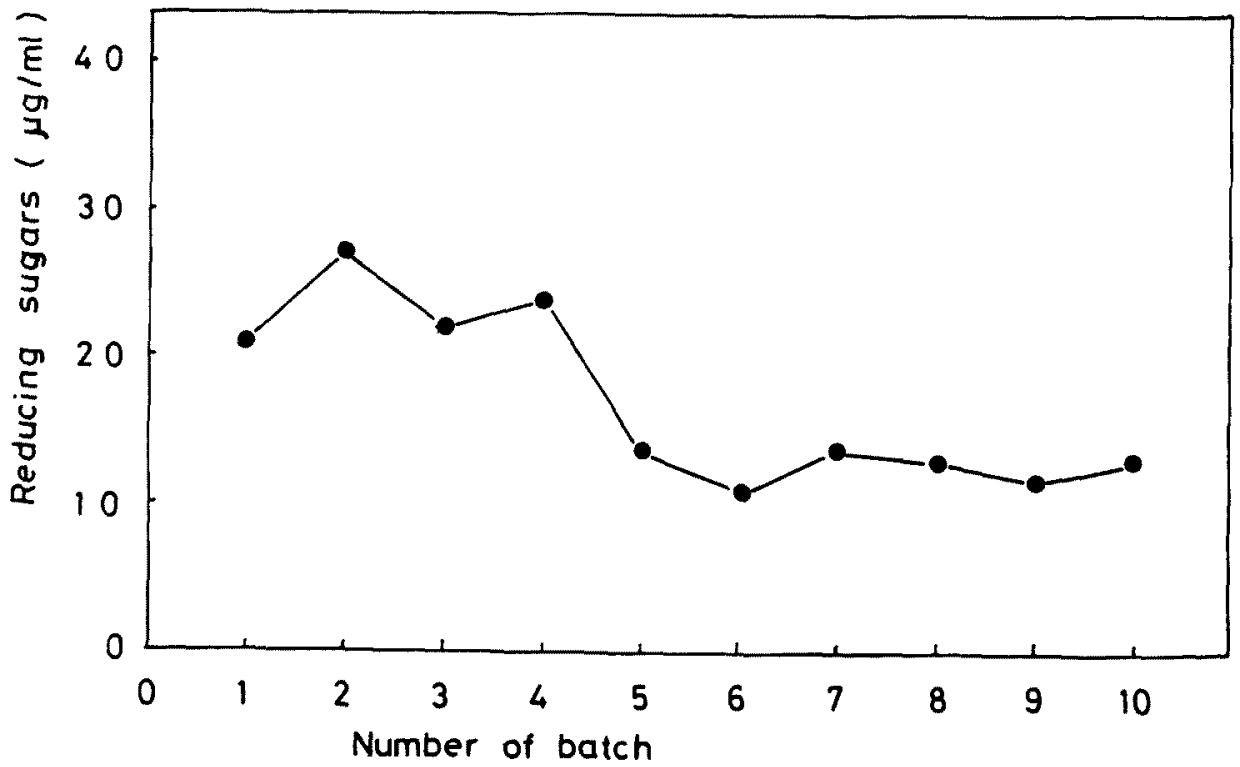

Fig. 3 The production of cellulase in repeated 6 -day batch culture by $T$. viride cells immobilized in chitosan gel beads: Experimental conditions are described in 2.4 . 
at each batch culture. Thus the cells of $T$. viride immobilized in gel beads seem to be viable throughout the repeated batch culture, effectively producing the enzyme. After the batch culture of 4 times, however, the enzyme activity went down to about $50 \%$ of the beginning value. Thereafter it showed no significant drop in activity even after the repeating use over 10 times. This indicates that gel beads were slightly loosened and that aliquotes of cells in gell beads leaked into the medium during repeated batch culture over 5 times (Fig. 2).

In conclusion, continuous culture of the immobilized cells for cellulase production is possible and the immobilized cells can be used for a reactor of enzyme production in continuous culture. Chitosan gel beads is useful for a cell-immobilization support for a bioreactor.

\section{References}

1. I. Chibata and T. Tosa, "Immobilized Microbial Cells", Academic Press, New York (1983).

2. T. Tosa, T. Mori, and I. Chibata, Appl. Microbiol., 27. 866 (1974)
3. K. Mosbach and P. O. Lavsson, Biotechnol. Bioeng., 12, 19 (1970).

4. G. K. A. Martin and D. Perlman, Biotechnol. Bioeng., 18, 217 (1976).

5. M. Kierstan and C. Bucke, Biotechnol. Bioeng., 19. 387 (1977)

6. M. Wada, J. Kato, and I. Chibata, Eur. J. Appl. Micro biol. Biotechnol., 8, 241 (1979).

7. T. Kokubu, I. Karube, and S. Suzuki, Eur. J. Appl. Microbiol. Biotechnol., 14, 7 (1982).

8. A. Shimizu, H. Kimura, and H. Okada, Eur. J. Appl. Microbiol. Biotechnol., 14, 7 (1982).

9. H. Kusaoke, T. Takemura, and H. Ichikawa, Sen'i Gakkaishi, 46, 122 (1990).

10. H. Kusaoke, K. Suzuki, and K. Kimura, Sen $i$ Gak. kaishi, 44, 402 (1988).

11. M. Kumakura and I. Kaetsu. Biotechnol. Appl. Biochem., 8, 195 (1986)

12. H. Seo, Sen $i$ Gakkaishi, 46, P-564 (1990).

13. M. Somogyi, J. Biol. Chem., 195, 19 (1952). 